\title{
The Soviet Press of the Great Patriotic War about the French Squadron "Normandie-Niemen"
}

\author{
G. N. Kaninskaya ${ }^{1}$, N. N. Naumova ${ }^{2}$
}

${ }^{1}$ P. G. Demidov Yaroslavl State University, 14 Sovetskaya str., Yaroslavl 150003, Russian Federation ${ }^{2}$ Lomonosov Moscow State University, 1 Leninskie Gory, Moscow 119991, Russian Federation

DOI: $10.18255 / 1996-5648-2021-1-6-19$

Research article Full text in Russian

The article is devoted to the participation of French pilots of the Normandy squadron in battles on the Soviet-German front as part of the Red Army in 1943-1945. After the defeat of France at the first stage of World War II (1940), the occupation of its territory by Germany and the organization of the Resistance movement "Fighting France" in London by General Charles de Gaulle, the pilots joined him expressed a burning desire to fight the enemy in the skies over Soviet soil. Their participation in the ranks of the Soviet Air Force was a unique event in the history of the Great Patriotic War of the Soviet Union (1945-1945). The article analyzes the information of the Soviet press during the war years about the French squadron "NormandieNiemen", which fought in the Soviet Air Force on the Soviet-German front. It is shown that Soviet readers during the Great Patriotic War could get a very complete and reliable idea of the military exploits of French pilots, find out the names of heroes, get acquainted with the military everyday life of officers, appreciate their patriotism and sincere friendly feelings for the Soviet Union and its people. Along with stories about the air battles of the Normandy, the articles of Soviet correspondents contained information about the history of France, how the pilots reacted to the defeat of their country, how and where they fought in the first stage of the Second World War. The press of the war years gave brief sketches of the everyday life of French fighters on Soviet soil, about the curious events that happened to the pilots of the squadron. On the example of newspaper publications 1943-1945. about the military alliance of our and French pilots, you can get an idea of how the cooperation of the countries of the anti-Hitler coalition developed and strengthened.

Keywords: Normandy; Fighting France; press; essays; interviews; squadron; fighters; Resistance; USSR

\section{INFORMATION ABOUT AUTHORS}

\author{
Kaninskaya Galina N. | E-mail: kaninsk6@mail.ru \\ Doc. Sc. (History), Professor \\ Naumova Natalya N. | E-mail: naumovafrance@yandex.ru \\ Cand. Sc. (History), Associate Professor
}

(C) Kaninskaya G. N., Naumova N. N., 2021

This is an open access article under the CC BY license (https://creativecommons.org/licenses/by/4.0/) 


\title{
Советская пресса периода
}

Великой Отечественной войны

о французской эскадрилье «Нормандия-Неман»

\author{
Г. Н. Канинская ${ }^{1}$, Н. Н. Наумова ${ }^{2}$
}

${ }_{1}^{1}$ Ярославский государственный университет им. П. Г. Демидова, ул. Советская, 14,
Ярославль, 150003, Российская Федерация
${ }^{2}$ Московский государственный университет им. М. В. Ломоносова, Ленинские горы, 1,
Москва, 119991, Российская Федерация

DOI: $10.18255 / 1996-5648-2021-1-6-19$

Научная статья

УДК 94(100)

Полный текст на русском языке

Статья посвящена участию фрранцузских лётчиков эскадрильи «Нормандия» в боях на советско-германском фронте в составе Красной Армии в 1943-1945 гг. После поражения Франции на первом этапе Второй мировой войны (1940 г.), оккупации её территории Германией и организации в Лондоне генералом Шарлдем де Голлем движения Сопротивления «Сражающаяся Франция» примкнувшие к нему лётчики выразили горячее желание сражаться с врагом в небе над советской землёй. Их участие в рядах советских ВВС стало уникальным событием в истории Великой Отечественной войны Советского Союза (1945-1945 гг.). В статье анализируется информация корреспондентов советских газет «Сталинский Сокол, «Красная звезда», «Известия», «Правда» о «Нормандии». Показано, что советские читатели в военные годы могли составить весьма полное и достоверное представление о военных подвигах фрранцузских лётчиков, узнать имена героев, познакомиться с военными буднями офицеров, оценить их патриотизм и искренние дружески чувства к Советскому Союзу и его народу. Наряду с рассказами о воздушных сражениях «Нормандии» статьи советских корреспондентов содержали инорорацию об истории Франции, о том, как реагировали лётчики на поражение своей страны, как и где воевали они на первом этапе Второй мировой войны. В прессе военных лет давались краткие зарисовки бытовой жизни французских истребителей на советской земле, о курьёзных событиях, случавшихся с пилотами эскадрильи. На примере газетных публикаций 1943-1945 гг. о боевом союзе наших и фрранцузских лётчиков можно составить представление о том, как развивалось и крепло сотрудничество стран антигитлеровской коалиции.

Ключевые слова: Нормандия; Сражающаяся Франция; пресса; очерки; интервью; эскадрилья; истребители; Сопротивление; СССР

\section{ИНФОРМАЦИЯ ОБ АВТОРАХ}

Канинская Галина Николаевна

Наумова Наталья Николаевна
E-mail: kaninsk6@mail.ru

Доктор исторических наук, профессор

E-mail: naumovafrance@yandex.ru

Кандидат исторических наук, доцент

(ㄷ) Канинская Г. Н., Наумова Н. Н., 2021

Статья открытого доступа под лицензией CC BY (https://creativecommons.org/licenses/by/4.0/) 
«В небесах мы летали одних, мы теряли друзей боевых.

Ну, а тел, кому въпало жить, надо помнить о них и дружить»

(Песня М. Бернеса на слова Е. Долматовского «Воспоминание об эскадрилье "Нормандия-Неман"»)

В истории Великой Отечественной войны, с момента окончания которой прошло 75 лет, существует немало примеров и доказательств того, что победа стран - участниц антигитлеровской коалиции «ковалась» совместными усилиями на многочисленных фрронтах. Однако вряд ли был ещё такой образец советско-французского военного братства, как участие полка французских лётчиков «Нормандия-Неман» на советско-германском театре боевых действий в составе Красной Армии. Свидетельством признания заслуг французов служит то, что их имена и фотографии находятся в числе около 33 млн участников Великой Отечественной войны, представленных в галерее «Дорога памяти», открытой к 75-летию Победы в парке культуры и отдыха «Патриот», что в подмосковном Алабине [1, с. 3].

\section{Из истории}

Идея послать французских лётчиков на Восточный фронт зародилась во французском Сопротивлении, в рядах движения «Сражающаяся Франция» во главе с находившимся в Лондоне генералом де Голлем, призвавшим из столицы Великобритании 18 июня 1940 г. всех свободных французов присоединяться к нему для продолжения борьбы на стороне антигитлеровской коалиции, после того как Франция потерпела поражение от Германии и была оккупирована немцами. В 1941 г. начальник генштаба «Сражающейся Франции» Эрнест Пети обратился с такой инициативой к де Голлю, а тот, в свою очередь, в ноябре того же года предложил советскому правительству принять участие французских подразделений на советско-германском фронте, в частности, эскадрильи французских лётчиков в составе Красной Армии. Советская сторона приглашение приняла, начались переговоры, продлившиеся до апреля 1942 г. Вели их с советской стороны посол СССР при союзных правительствах в Лондоне А. Богомолов, а с французской - М. Дежан, на то время руководитель департамента по политическим вопросам «Сражающейся Франции», будущий посол в СССР в годы созданной де Голлем в 1958 г. Пятой республики.

Французская сторона предлагала послать на советско-германский фронт 30 лётчиков и 30 человек обслуживающего персонала. По итогам дипломатических и военных переговоров 25 ноября 1942 г. в Москве было подписано «Соглашение между представителем командования Красной Армии и представителем военного командования «Сражающейся Фран- 
Советская пресса периода Великой Отечественной войны...

ции» об участии французских частей ВВС в операциях в Советском Союзе» под названием «Нормандия». Подписали его начальник штаба, заместитель командующего ВВС РККА генерал-лейтенант, будущий маршал авиации Ф. Фалалеев и глава фрранцузской военной миссии в СССР бригадный генерал Э. Пети.

«Соглашение» состояло из 14 пунктов и, по сути, фриксировало инкорпорацию французских лётчиков в состав советских ВВС, не делая различий между фрранцузами и советскими авиаторами. В частности, один из пунктов гласил, что эскадрилья «участвует в боевых действиях по заданию и в порядке, установленном командиром соединения, в которое она включена. Командование эскадрильей и ее действиями в бою осуществляется фрранцузским командиром, а при совместном участии в бою с другими подразделениями или частями соединения командование осуществляется командиром, назначенным командиром соединения» [2, с. 33]. Подчёркивалось также, что советское командование предоставит французской эскадрилье материальную часть и в «случае необходимости дополнительный персонал с тем, чтобы обеспечить ей максимум успеха в боевой работе» [2, с. 41]. В отдельных пунктах «Соглашения» оговаривались порядок награждения фрранцузских пилотов, то есть какими наградами - национальными или советскими, и даже порядок привлечения к ответственности за проступки.

Эскадрилья, получив первоначально название «Нормандия», стала формироваться в сентябре 1942 г. на авиабазе Раяк в Сирии - в колонии Франции. Был подписал приказ № 3 о создании фрранцузской авиагруппы для вхождения в состав Красной Армии. Состояла группа из 14 пилотов, 25 техников, 15 бортстрелков, двух пилотов связи, врача и переводчика. Добирались они до Советского Союза на советских транспортных самолетах через Иран, Азербайджан и Казахстан два с половиной месяца. Прибыв в СССР 2 декабря 1942 г., эскадрилья разместилась на отведённом в окрестностях Иваново аэродроме, где ей предстояло освоить советские истребители «Як»-1, отличавшиеся от английских «Девуатинов», на которых они летали в начале войны. Освоение новой лётной техники заняло 3 месяца, и 14 марта 1943 г. начальник управления формирования и укомплектования ВВС Красной Армии генерал-лейтенант авиации Алексей Никитин доложил наркому иностранных дел В. Молотову о завершении подготовки.

Поначалу прибывшую на фронт 22 марта «Нормандию» включили в состав бомбардировочной авиации - в 204-ю бомбардировочную авиадивизию 1-й Воздушной армии. Боевой задачей лётчиков считалось сопровождение бомбардировщиков и оборона аэродрома от вражеских налетов, за которой скрывалось стремление советского командования оградить летчиков от больших потерь. Но представители фрранцузской 
Канинская Г. Н., Наумова Н. Н.

военной миссии, равно как и сами лётчики, решительно добивались того, чтобы участвовать в боях как истребители, и в итоге 1 апреля 1943 года «Нормандию» включили в состав 18 гвардейского истребительного полка 303-й истребительной авиадивизии той же воздушной армии.

Первые победы в советском небе одержали 5 апреля 1943 г. фрранцузские лётчики А. Пресиози и А. Дюран, сразившись с двумя немецкими истребителями «Фокке-Вульф». После окончания Второй мировой войны лётчики «Нормандии-Неман» на подаренных советским правительством истребителях «Як-3» вернулись во Францию, где до сих пор свято чтят память их совместных сражений на фронтах Великой Отечественной войны Советского Союза. Именами шестерых погибших летчиков знаменитого авиаполка были названы французские авиабазы (некоторые уже не существуют.- Г. К.; H. Н.): капитана Мориса де Сейна - в Оранже; первого командира «Нормандии» и ее первого погибшего летчика майора Ж⿱㇒ана Тюляна - в Турсе; капитана Альбера Пресиози - на Корсике, Шарля Монье - в Истре; братьев Ива, Жћана и Клода Маэ - в Таверни; капитана Альбера Литольфа - в Контрексвиле.

\section{В сводках значились}

В условиях сурового военного лихолетья Великой Отечественной войны советский народ, поддерживая бойцов Красной Армии своим героическим трудом в тылу, внимательно следил за событиями на передовой. С нетерпением ожидали вестей о жизни в стране и на линиях фрронтов. Так крепли боевой дух советского народа и уверенность в победе. Главными источниками информации служили официальные сообщения Советского Информбюро, передававшиеся по радио и громкоговорителям, а также неоценимую роль играли газеты, выпуск которых не прекращался ни на день. Таким образом, о единственном и памятном фракте в истории боевых сражений Красной Армии - участии французских лётчиков-истребителей непосредственно на советско-германском фрронте граждане обеих стран узнавали по мере развития событий.

Советские читатели военных лет могли проследить боевой путь эскадрильи «Нормандия» по горячим следам, начиная с 1943 г. Наиболее подробно о ней сообщали общенациональные военные газеты: «Красная звезда» - ежедневный и на то время значившийся как Центральный орган Народного комиссариата обороны Союза ССР и «Сталинский Сокол» - орган ВВС Красной Армии, издававшейся Наркоматом обороны СССР с 1941 г. один раз, а с 1943 г. - два раза в неделю. Не обошли вниманием «Нормандию» и официальные правительственные общенациональные ежедневные газеты «Правда», в то время Орган ЦК и MК ВКП(б), и «Известия» - орган Совета депутатов трудящихся СССР.

Несмотря на то что общее число корреспонденций, посвящённых фрранцузской эскадрилье за время 1943-1945 гг. было невелико (в «Крас- 
ной звезде» - 7, в «Сталинском Соколе» - 9, в «Правде» - 3, в «Известиях» - 5), по содержавшейся в них информации уже тогда можно было в общих чертах (насколько это позволяли условия военного времени) узнавать о сражениях и подвигах фрранцузов, воевавших на советско-германском фрронте вместе с советскими лётчиками. Статьи о «Нормандии» публиковались обычно на 3-й или 4-й, а иногда на 1-й страницах в сводках, посвящённых военным операциям советских ВВС. Таким образом, в информационном потоке о боевых сражениях Красной Армии французские лётчики органически соединились с советскими ВВС, что для нас сегодня служит подтверждением братского духа и единства СССР и Франции на полях сражений Великой Отечественной войны, во время которой у советского читателя не могла не крепнуть вера в сплочённость союзников и скорую победу.

Первое сообщение под заголовком «Бой французских лётчиков» появилось в виде передовицы с подзаголовком «Действующая армия» на 1-й странице газеты «Красная звезда» 9 апреля 1943 г., то есть через 4 дня после первых сражений французов с немецкими истребителями. В других номерах газет корреспонденции о «Нормандии», даже если подписывались авторами, всегда сопровождались подзаголовком «Действующая армия».

Начинался текст так: «Летчики-французы авиационной эскадрильи «Нормандия» с нетерпением ждали того дня, когда они поднимутся в воздух на советских самолётах, чтобы поражать ненавистных гитлеровцев. Первыми получили боевое задание лейтенант Дюран и старший лейтенант Проциози (в текстах военных корреспонденций так иногда транскрибировали gбамилию Пресиози. - Г. К., Н. Н.). Им было поручено прикрывать два наших бомбардировщика». Далее шло описание воздушного боя.

Текст заметки невелик и не сопровождался какими-либо подробностями. Более детальная информация о французской эскадрилье появилась в «Сталинском Соколе» 23 апреля 1943 г. за подписью Л. Лерова под названием «Нормандия».

Рассказ Л. Лерова был исчерпывающим. «Мы находимся в общежитии французских лётчиков, прибывших в СССР, чтобы вместе с русскими драться за победу свободолюбивых народов над фрашизмом», - так начинается материал автора [3, с. 4]. Далее воспроизводится беседа с фрранцузскими лётчиками о выполнении боевого задания: «Сегодня они ходили прикрывать бомбардировщиков и видели, как рвались бомбы, точно сброшенные на железнодорожную станцию. Цель находилась в глубине обороны противника. И командир французской эскадрильи, отправляясь в полёт, лелеял надежду, что сегодня удастся померяться силами в воздухе - встретиться с истребителями врага. "Увы, надежда не оправдалась”, - говорит командир с извиняющейся улыбкой. Он понимает, что нельзя 
Канинская Г. Н., Наумова Н. Н.

сожалеть об отсутствии воздушного противника в момент действий наших бомбардировщиков. Но у этого француза - душа истребителя и горячее сердце, жаждущее боя и мщения» [3, с. 4].

Не обошёл вниманием корреспондент и историю создания авиаполка. «Эскадрилья носит название «Нормандия». Это - название провинции, - поясняет Л. Леров, - с которой особенно жестоко расправились немецкие оккупанты. В эскадрилью вошло много отличных фрранцузских лётчиков-истребителей, тайком бежавших из Франции после капитуляции правительства Виши. Среди лётчиков «Нормандии» - знаменитый фрранцузский ас, признанный воздушный виртуоз. Во главе «Нормандии» потомственный воин. Он высоко чтит традиции предков, дравшихся с немцами и в 1871 , и в 1914 гг.» [3, с. 4].

С гордостью за советскую авиационную промышленность Л. Леров сообщает, что фрранцузы на вопрос о том, на каких воздушных машинах они хотели бы летать, ответили: «Вместе с русскими мы будем воевать на русском самолёте», - и цитирует их командира: «"Як” - самый лучший самолёт, на котором я летал. А я в авиации уже более 10 лет» [3, с. 4].

По сути, в статье Л. Лерова можно уловить те фракты, которые в условиях военного времени носили конфиденциальный характер и не предназначались для широкого круга читателей, а стали известны лишь в послевоенные годы. Например, не разглашалось «Соглашение между представителем командования Красной Армии и представителем военного командования “Сражающейся Франции» об участии французских частей ВВС в операциях в Советском Союзе», в котором говорилось о мерах привлечения к ответственности за проступки; не афишировалось недовольство французских лётчиков тем, что поначалу им не поручалось участие в боях как истребителей. Вот что отмечал Л. Леров: «Лётчики «Нормандии» понимают, что каждый удачный бомбовый удар - это победа и истребителей прикрытия. Так говорит их трезвый ум. А сердце жаждет воздушного боя. Один из лётчиков рассказывал нам, как тяжело ему было сдержать себя в момент, когда он, сопровождая бомбардировщиков, увидел шедших стороной “ФВ-190” < .. > И когда случилось однажды, что в полёте не выдержал молодой лётчик и, увидев в стороне «ФВ-190», ринулся в погоню за ним, командир резко зашёл вперёд, перерезал курс пилоту, помахал крыльями и заставил его вернуться в строй. А на земле у молодого пилота был испорчен весь вечер - так его отчитывал командир <..> Недавно в эскадрилье был большой праздник: состоялась долгожданная битва в воздухе. Лётчики Д-н и П-и, сопровождая бомбардировщиков, вели воздушный бой с двумя «ФВ-190». Немцы атаковали ведущего Д-на $<$...> Немец, решив, что Д-н сбит, оставил его в покое и ушёл с набором высоты. Но его настиг второй французский лётчик - П-и. С короткой дистанции “ФВ-190” был сбит. Эту первую победу праздновала вся эскадрилья. 
Французы открыли счёт сбитых самолётов. И больше всех ликовал юный П-и. Если у Д-на это была пятая победа (он уже имел на своем счету четыре сбитых самолёта), то П-и впервые в жизни вёл воздушный бой с немцами. Так началась новая эра в жизни группы фрранцузских патриотов» [3, c. 4$]$.

Л. Леров не раскрывает фрамилии лётчиков, хотя явно речь шла о Дюране и Пресиози. Объяснение такой секретности мы находим у корреспондента «Известий» А. Булгакова: «У каждого из лётчиков во Франции, стонущей под игом немецких оккупантов, остались семья, родные или близкие люди, и по понятным для читателей причинам мы будем называть вместо фрамилий лётчиков лишь их инициалы» [4, с. 4]. Статья А. Булгакова, для которой «Известия» отвела 4 колонки, пронизана глубокой симпатией к французским лётчикам, их героизму и патриотизму, а через них - верой в дружбу СССР и Франции и их совместную победу в Великой Отечественной войне. Вот несколько отрывков: «Одеты они были в свою форму - тёмные куртки с открытым воротником, тёмные остроконечные пилотки с золотыми треугольничками и бронзовой птицей с распростёртыми крыльями. На правом предплечье нашивка серебряными буквами «France» <..> Все они за время войны прошли сложный, трудный и разнообразный боевой путь, всех их привела на наш фрронт одна цель - борьба с гитлеровской Германией, борьба за освобождение родины от немецких оккупантов. Большинство из лётчиков эскадрильи дерутся с немцами с первых же дней войны <..> Все лётчики эскадрильи с радостью восприняли приказ своего командования о назначении на русский фрронт, так как здесь, говорят они, «немцы под боком и их можно бить каждый день, каждый час» [4, с. 4]. И об отношении к Советскому Союзу и его гражданам: «Все советские командиры, с которыми мы работаем, в короткое время стали нашими боевыми товарищами. Мы были свидетелями того, как Красная Армия бьёт немцев и как немцы бегут под ударами Красной Армии. Настроение русского народа боевое. Все много работают, и никто не сомневается в разгроме фашистской Германии. Героическая и успешная борьба Красной Армии вселяет в нас надежду, что мы скоро сумеем общими силами разгромить врага и освободить Францию от гитлеровских оккупантов» [4, с. 4]. Слова эти сказаны были в беседе с А. Булгаковым командиром эскадрильи, обозначенным, как майор Т., на деле Жаном Тюляном.

Удалось побеседовать с ним и корреспонденту «Красной звезды» майору Я. Милецкому, опубликовавшему свой рассказ 26 мая под заголовком «Боевые успехи французских лётчиков». Он называет его Жћан Т., описывая его так: «В фрорме фрранцузского лётчика - короткой тёмносиней ( в тексте. $-\Gamma . K$., H. H ) куртке спортивного покроя - он казался моложе своих тридцати лет. Внешний вид майора типичен для лётчика-истре- 
Канинская Г. Н., Наумова Н. Н.

бителя: он небольшого роста, стройный, лёгкий и быстрый в движениях. Майор Ж⿱ан Т. приехал к нам, уже обладая большим опытом. Он участвовал в ливийской кампании 1941 года <...> О боевом опыте майора говорят и три орденские ленточки на его куртке» [5, с. 3]. Со слов Ж⿱. Тюляна, уже на момент беседы «число сбитых вражеских самолётов почти удвоилось против того количества машин, которое наши лётчики сбили раньше, в Англии и Ливии» [5, с. 3].

В статье приводятся следующие данные об успехах лётчиков: «Уничтожено шесть немецких самолётов и, вероятно, сбиты ещё три самолёта. На аэродромах противника уничтожено шесть одномоторных самолётов и два двухмоторных. Во время одной штурмовки уничтожено или повреждено 43 грузовика, две легковых автомашины, железнодорожный эшелон (отмечено восемь прямых попаданий в вагоны), подожжены станционные здания» [5, с. 3]. Ж . Тюлян высоко оценивал советские «Яки», подчёркивая: «Растёт и наша эскадрилья “Нормандия". Мы не хотим отстать от русских союзников. Мы готовим лётчиков из числа офицеров Сражающейся Франции и вводим их в строй» [5, с. 3]. С особой теплотой фрранцузский майор отзывался о приёме на советской земле. «Нам созданы все условия для боевой работы», - цитирует его Я. Милецкий [5, с. 3]. А. Булгаков и Я. Милецкий описали, как выглядят «Яки», на которых летают фрранцузы: «На крыльях их были звёзды. Только на борту самолёта вместо звёзд были нанесены круги - последовательно - синий, белый и красный. Цвета национального фрлага Франции» [5, с. 3].

О признании заслуг фрранцузских лётчиков в боях на советском воздушном фрронте говорит Указ Президиума Верховного Совета СССР «О награждении офицеров состава воинской части Сражающейся Франции - «Нормандия», опубликованный 3 июля 1943 г. в «Известиях» и «Красной звезде». Награждались: майор Тюлян Жан Луи и капитан Литольф Альберт - Орденами Отечественной войны I степени, а лейтенанты Дюран Альберт, Лефевр Марсель и Аджюдан-шеф Дюпра Луи (по-нашему, старший сержант. - Г. К., Н. Н.) - II степени. В обеих газетах в тот же день на 3-й странице корреспонденты соответственно А. Булгаков и Л. Никулин напечатали интервью с награждёнными, которые рассказывали о себе и своих товарищах по эскадрилье [6, с. 3; 7, с. 3]. С этого времени уже можно было встретить в газетных очерках полные имена французских героев. 9 июля в «Сталинском Соколе» в статье «Французские лётчики» в той же тональности писал Л. Леонидов: «В землянке слышен звучный французский говор, в котором сливается речь парижанина и эльзасца, марсельца и нормандца. Мы на командном пункте эскадрильи “Нормандия" - эскадрильи лётчиков Сражающейся Франции. На стене рядом с картой, испещрённой красными и синими стрелами, - французский плакат: «Ко всем фрранцузам! Франция проиграла битву, но Франция 
не проиграла войну». Это девиз нашей эскадрильи, - поясняет майор Жан Луи Тюлян, заметивший наш взгляд, обращённый на плакат» [8, с. 4].

В 1943 г. военные газеты ещё по одному разу рассказывали читателям о «Нормандии». «Сталинский Сокол», отметив, что «за последние дни боёв образцы замечательного лётного мастерства и бесстрашия показали французские лётчики группы «Нормандия», поместил небольшую заметку о конкретном воздушном сражении, упомянув как его героев фамилии Риссо, Бальку, Лефевра, Бегена, Барнье, Ж⿱㇒анеля, и подчеркнул: «В этом бою славные лётчики "Нормандии" сбили 4 бомбардировщика, не понеся потерь» [9, с. 1]. В декабре этого года, когда всё очевиднее становилось, что близится победа союзников по антигитлеровской коалиции во Второй мировой войне, обстоятельный анализ действий французов в небе над нашей землёй в статье «Воздушные бои «Нормандии» дал в «Красной звезде» подполковник Н. Денисов. «В журнал боевых действий группы лётчиков-истребителей Сражающейся Франции «Нормандия», ведущих бои с немцами на советско-германском фронте, недавно была вписана цифра 100. За сравнительно короткое время фрранцузы-патриоты уничтожили и подбили в воздушных боях 100 немецких самолётов» [10, с. 4], - начинал свой обзор Н. Денисов. В этом обзоре обрисована история пребывания фрранцузских лётчиков в СССР с первых дней. «Выполняя задания по сопровождению наших бомбардировщиков и штурмовиков, фрранцузские лётчики на первых порах столкнулись с некоторыми трудностями, - пишет Н. Денисов. - Известно, что этот вид взаимодействия требует непрерывной взаимной связи между лётчиками всех групп < ..> Требовалось исключить те недоразумения, которые могли возникнуть в совместном полёте русских и французских лётчиков из-за отсутствия общего разговорного языка...Успешная боевая работа во многом определяется тщательной предварительной подготовкой и работой после полётов <...> Воздушные бои «Нормандии» уже нанесли немцам немалый урон. Французские патриоты сражаются крылом к крылу с советскими лётчиками. Они жестоко мстят гитлеровцам за поруганную Францию, за свой народ» [10, с. 4].

Пик публикаций о лётчиках «Нормандии» в советских газетах пришёлся на 1944 г. в связи с важнейшими событиями как в истории Второй мировой войны, так и в истории советско-французских отношений. Во-первых, в августе 1944 г. Франция была освобождена союзниками от немецкой оккупации, к власти пришло Временное правительство во главе с генералом де Голлем, заявившее, что будет сражаться с Германией на стороне антигитлеровской коалиции до победного конца, и 2-10 декабря состоялся визит де Голля в СССР, по итогам которого в Кремле был подписан «Договор о союзе и взаимной помощи». О пребывании де Голля в кратком коммюнике сообщала «Правда» и более подробно, с публикацией текста 
Канинская Г. Н., Наумова Н. Н.

договора, - «Известия» $[11$, с. $1 ; 12$, с. 1]. В передовице «Известий», озаглавленной «Советско-фрранцузский союз», подчёркивалось, что этот договор «с большим удовлетворением воспримет Красная Армия и весь советский народ» и что "народы СССР и Франции, находившиеся в течение многих десятилетий под угрозой нападения со стороны Германии, всегда рассматривали друг друга как естественных союзников в борьбе против общего врага» [11, с. 1].

Во-вторых, важное событие касалось непосредственно эскадрильи, которой незадолго до визита главы Франции в нашу страну, 28 ноября, было присвоено звание «Неманская», а два её летчика - А. Марсель и Р. де ля Пуап - в начале года удостоились звания «Герой Советского Союза». Интервью с ними вместе с портретами поместили все газеты. Упоминались также и другие лётчики, награждённые Орденами Отечественной войны I и II степени. Сами за себя говорят и заголовки газетных статей: «Доблестные лётчики Нормандии», «Слава «Нормандии», «Герои «Нормандии», «Славные сыны Франции [13, с. 5; 14, с. 3; 15, с. 3; 16, с. 3]. Одним из авторов публикаций был И. Эренбург, текст которого из «Красной звезды» перепечатала «Правда» [13, с. 5].

Известный советский писатель отмечал: «Лётчики “Нормандии” приехали к нам осенью 1942 г. Нас тогда не было в Восточной Пруссии, немцы тогда были у Волги <..> А за границей гадали, сколько недель мы ещё продержимся? И вот в ту тёмную осень наши французские друзья, фрранцузские лётчики прилетели к нам. Они поняли нашу силу и поверили в нашу дружбу. Франция теперь освобождена от захватчиков <..> Но мы её признали, когда она была ещё в цепях. И французы этого не забудут» [16, с. 2]. В сводке «Действующая армия» 30 ноября «Правда» рассказала о митинге в полку теперь уже «Нормандия-Неман» в связи с награждениями [16, с. 3]. В свою очередь, «Известия» напечатали статью «Мы летаем на «Яках», написанную самими французами [17, с. 3].

В корреспонденциях 1944 г. не только печатались полные имена французских лётчиков, но уже не были тайной места их боевых сражений. Стало известно, что начали они сражаться в воздушных боях под Сталинградом, перечислялись цифры и данные о других сражениях в небе, передавались многочисленные рассказы лётчиков о жизни у себя в стране и в СССР. В газетах появилось много фотографий. «Вместе с другими лётчиками фрранцузской авиационной части "Нормандия" мы били немцев над Орлом и Смоленском, над Оршей и Витебском, над землёй Восточной Пруссии, - говорилось, например, в «Известиях». - Мы приехали в СССР в разное время, но каждый испытал одно чувство: мы попали в страну великого мужества. Здесь все полны решимости драться с врагом <..> Сейчас, когда лётчикам “Нормандии” приходится летать над территорией противника и когда окончательная победа близка, нам очень приятно 
осознавать, что в боях на Восточном фронте мы обрели прекрасных друзей» $[17$, с. 3$]$.

В победный 1945 г. «за образцовое выполнение боевых заданий командования на фрронте борьбы с немецкими захватчиками и проявленные при этом отвагу и мужество» соответствующим Указом Президиума Верховного Совета СССР Орденом Красного знамени, Орденами Отечественной войны I и II степени, а также Орденом Александра Невского было награждено в общей сложности 24 французских лётчика. Кроме того, Орден Красного знамени получил глава Французской военной миссии в СССР Э. Пети с формулировкой: «За успешную военную деятельность и заслуги в деле организации борьбы против общего врага Советского Союза и Франции - гитлеровской Германии» [18, с. 5].

8 июня 1945 г. «Красная звезда» напечатала беседу своего спецкора, не назвав его фрамилию, с новым командиром воинской части Сражающейся Франции «Нормандия» полковником Луи Дельфино, назначенным после гибели первого командира ж九. Тюляна в воздушном бою во время Орловского сражения, о чём и поведал новый командир. Л. Дельфино назвал имена двух других павших офицеров: М. Лефевра, ставшего Героем Советского Союза посмертно, и А. Литольфа, погибшего вместе с ж⿱. Тюляном. В конце войны список Героев Советского Союза, как сообщил Л. Дельфино, пополнился ещё двумя офицерами: М. Лефевром, награждённым посмертно (погиб 6 июня 1944 г.), и Ж⿱乛. Андре.

Подводя итоги военным действиям своих однополчан, Л. Дельфино сказал: «Французские лётчики совершили около 4 тысяч боевых вылетов, провели 869 воздушных боёв. Противнику нанесены следующие потери: сбито более 270 немецких самолётов, повреждено 80 самолётов. Кроме того, разбито много вражеской техники, поездов, автомашин, катеров. Наши потери выражаются в следующих цифрах: 14 убитых лётчиков, 30 пропавших без вести, 6 тяжело раненых» [19, с. 3]. Отметив высокие боевые качества советских «Яков» и рассказав о некоторых эпизодах боевой жизни, Л. Дельфино заключил: «Мы глубоко тронуты гостеприимством, оказанным нам населением Советского Союза и воинами Красной Армии. Лётчики “Нормандии” будут лучшими пропагандистами постоянной фрранко-советской дружбы» [19, с. 3].

С присущим ему незаурядным литературным талантом, полным героизма, написал 9 июня 1945 г. в «Известиях» большую статью о «Нормандии-Неман» по случаю возвращения лётчиков на родину на подаренных советских самолётах «Як-3» И. Эренбург. «Теперь у нас нет отбоя от друзей, - кому не лестно примоститься хотя бы на крылечке у победителя? - спрашивал он. - Вспомним другое время. Лето 1942 года было чёрным для Советского Союза и для всей Европы <..> В то тёмное и горькое лето $<\ldots>$ два десятка фрранцузских лётчиков, которым удалось вырваться 
Канинская Г. Н., Наумова Н. Н.

из фашистской неволи, заявили о своём желании сражаться на советско-германском фронте <..> Они пришли к нам, когда нам было тяжело, и мы этого не забудем <..> Мы помним всех; и теперь, провожая друзей, улетающих во Францию, мы знаем, что они оставляют на нашей земле дорогие могилы <..> Париж скоро встретит "Нормандию”: на груди победителей он увидит рядом с фрранцузскими советские ордена; он увидит на прославленных самолётах рядом с красной звездой трёхцветную кокарду. Пройдут года, зарастут раны <..> мир станет прочным, глубоким, $<\ldots>$ но никогда не забудется боевая дружба <..> Вы честно воевали, и славным останется в истории Французской республики имя Неманского полка» [20, с. 4].

Подробно картину процедуры награждения фрранцузских лётчиков, состоявшегося 5 июня 1945 г. в Голубом зале Центрального Дома Красной Армии в присутствии Чрезвычайного и полномочного посла Французской республики в СССР генерала Катру, главы Французской военной миссии в СССР дивизионного генерала Э. Пети и министра иностранных дел Временного правительства Франции Ж . Бидо, описал в «Сталинском Соколе» Л. Леров [21, с. 3]. С советской стороны главными на этой церемонии выступили заместитель Народного комиссара иностранных дел С. А. Лозовский, главный маршал авиации Герой Советского Союза А. А. Новиков, а также другие представители высшего военного командования СССР.

Особо хочется подчеркнуть полезность и важность непосредственного знакомства с газетными публикациями военных лет о «Нормандии-Неман». Советские корреспонденции были «живыми» по стилю, содержали инорормацию о курьёзных событиях из жизни французских лётчиков. Например, о том, как выпрыгнувших с парашютами на колхозное поле двух лётчиков, не говоривших по-русски, сначала местные жители чуть было не приняли за немцев, а когда всё прояснилось, устроили им горячий приём.

Таким образом, через прессу периода Великой Отечественной войны мы можем «погрузиться» в ту атмосферу, увидеть, что советские читатели в условиях военных лет и военной тайны могли узнать о боях Красной Армии и оценить информацию с позиций сегодняшнего дня. Прессу по праву следует рассматривать как важный исторический источник, дополняющий имеющуюся на сегодняшний день обширную научную и мемуарную литературу об эскадрилье «Нормандия-Неман».

\section{Ссылки}

1. Хайремдинов Л., Дуденко А. «Дорога памяти» ведёт к сплочению страны // Красная звезда. 2019. 13 ноябр., № 127.

2. Дыбов С. В. «Нормандия-Неман». Подлинная история легендарного авиаполка. М.: Эксмо, 2011. 320 с. 
Советская пресса периода Великой Отечественной войны...

3. Леров Л. «Нормандия» // Сталинский Сокол. 1943. 23 апр., № 17 (145).

4. Булгаков А. «Нормандия» // Известия. 1943. 9 мая, № 108 (8101).

5. Милецкий Я. Боевые успехи фрранцузских лётчиков // Красная звезда. 1943. 26 мая, № 122 (5493).

6. Булгаков А. Лётчики «Нормандии» // Известия. 1943. 3 июля, №155 (8148).

7. Никулин Л. «Нормандия» сражается // Красная звезда.1943. 3 июля, № 155 (5526).

8. Леонидов Л. . Французские лётчики // Сталинский Сокол. 1943. 9 июля, № 28 (156).

9. Эль-Регистан. Победа лётчиков «Нормандии» // Сталинский Сокол. 1943. 16 окт., № 45 (173).

10. Денисов Н. Воздушные бои «Нормандии» // Красная звезда. 1943. 15 дек., № 2955 (5666).

11. Известия. 1944. 19 дек., № 298 (8600).

12. Правда. 1944. 29 ноябр., № 286 (9743).

13. Правда. 1944. 30 ноябр., № 287 (9744).

14. Постословский М. Доблестные лётчики «Нормандии» // Сталинский Сокол. 1944. 16 февр., № 14 (208).

15. Рыбак Н. Слава «Нормандии»// Сталинский Сокол. 1944. 29 ноябр., № 93 (290).

16. Эренбург И. Герои «Нормандии» // Красная звезда. 1944. 28 ноябр., № 281 (5961).

17. Капитан Жанель, старший лейтенант Аммарже, младший лейтенант Эммоне, младший лейтенант Эйшенбауи. Мы летаем на «Яках» // Известия 1944. 12 дек., №292 (6594).

18. Правда. 1945. 7 июня, № 135 (9906).

19. Лётчики «Нормандии» возвращаются на родину // Красная звезда. 1945. 8 июня, № 133 (6121).

20. Эренбург И. Полк «Нормандия-Неман» // Известия. 1945. 9 июня, № 134 (8744).

21. Леров Л. Награды героям «Нормандии» // Сталинский Сокол. 1945. 9 июня, № 46 (344). 